Ann. Biol. anim. Bioch. Biophys., 1979, 19 (4 B), 1289-1295.

\title{
Experimentally produced changes in the structure and function of the gonads of mammalian and avian embryos
}

\author{
par J.-P. WENIGER, J. J. THIÉBOLD
}

Laboratoire de Zoologie et d'Embryologie expérimentale, Universifé Louis-Pasteur, 12 rue de l'Université 67000 Strasbourg, France.

\begin{abstract}
Summary. This is a survey of the work intended to contribute to our knowledge of normal gonadal sex differentiation in birds and mammals. Special attention has been given to the fate of germ cells in a foreign environment. The original work was undertaken to support the concept of a meiosis-inducing substance. Gonads were combined in heterosexual pairs and grown in organ culture. Homoplastic, heteroplastic, as well as xenoplastic combinations were composed. Germ cells in the testes were always of a spermatogonial type. It is concluded that still more experimental data will be necessary before the concept of a meiosis-inducing substance is acceptable. Our work on the effect of a higherthan-normal incubation temperature on the hormonal activity of the chick testis is also mentioned. It is suggested that the Müllerian inhibiting activity and the inhibitory effect on ovarian development, shown after testis grafting, depend on one and the same substance which is temperature sensitive.
\end{abstract}

\section{Introduction.}

Gonadal sex differentiation is a fundamental step in vertebrate ontogenesis. Disrupting the normal course of this differentiation has long been a favorite method towards an understanding of it. Parabiosis, graft or culture of gonads, steroid treatment and modification of temperature conditions are techniques which have been used successfully. Complete sex reversal has been obtained in amphibians and in birds. In mammals, however, sex reversal has so far been incomplete. We consider in this paper the detailed results of these procedures, first in mammals, then in birds.

\section{A. - Mammals}

In mammals, the freemartin offers a valuable example of gonadal sex modification (Jost ef al., 1973). After initial cortical inhibition, seminiferous cords and Leydig cells between them may form in the medullary zone. These newly formed cords may contain germ cells which degenerate before birth (Short et al., 1969). Cells from the 
male co-twin do not seem to contribute to producing the freemartin condition (Vigier et al., 1976) ; thus, the hormone theory of Lillie (1916) and Keller and Tandler (1916) remains valid.

Numerous attempts have been made to reproduce the freemartin condition by gonad graft or culture. As in the freemartin, ovarian inhibition by a neighbouring testis is the general rule (Macintyre, 1956 ; Salzgeber, 1963 ; Ozdzenski et al., 1976). Seminiferous-like tubules may form in these inhibited ovaries.

Papers by Turner and Asakawa (1964) and by Turner (1969) claimed that seminiferous tubules containing both oocytes and spermatocytes had formed in the ovarian part of the composite graft. In these authors' opinions, both types of germ cells were $X X$ cells, and they concluded that female germ cells could undergo spermatogenesis. This is contrary to what happens in the freemartin gonad, where the germ cells disappear from the seminiferous cords before birth, as already stated (Short ef al., 1969).

Let us now look at work on the fate of germ cells in an unusual environment.

The presence of $X Y$ germ cells in the gonads of the freemartin has not yet been demonstrated. On the other hand, XX germ cells have been claimed to survive in the testes of the male co-twin until sexual maturity (Teplitz et al., 1967 ; Weiss and Hoffmann, 1969), but this is a matter of controversy (Dunn ef al., 1968 ; Evans et al., in Tarkowski, 1969).

Chimaeric mice obtained by the fusion of two cleaving eggs of opposite sex are most often of male phenotype, and only a few chimaeras develop as females. One offspring of a chimaeric female had genetic characters that implied it had arisen from a Y-bearing oocyte (Ford et al., 1975). In a subsequent study, meiotic figures from another female chimaera provided proof that male germ cells could indeed become functional oocytes (Evans et al., 1977).

In phenotypically male chimaeras, XX germ cells enter into meiosis like normal oocytes, and then disappear from the testes in early postnatal life (Mystkowska and Tarkowski, 1968 and 1970 ; Tarkowski, 1969).

An autosomal dominant gene mutation causes genetic females to develop as phenotypic males in the goat (Hamerton ef al., 1969) and in the mouse (Cattanach et al., 1971). Germ cells are present in the testes of these intersexual animals during fœetal life, but none remain shortly after birth.

Thus, evidence favours the view that $X X$ germ cells cannot survive in a testicular environment. It seems safe to suppose that the oocyte-containing seminiferous tubules described by Turner and Asakawa (1964) belonged to the testicular part of the graft, and that the oocytes were the only remnant of the ovarian component.

In heterosexual grafts, a minor degree of testicular inhibition has previously been reported (Macintyre et al., 1959). In more recent culture experiments, the ovary was found to initiate meiosis precociously in male germ cells. This observation led to the hypothesis that the ovary might produce a meiosis-inducing substance (Byskov and Saxén, 1976; O and Baker, 1976). Heteroplastic and xenoplastic combinations were tried in order to ascertain whether this substance was interspecifically active, but no positive results have been obtained so far (Weniger and Thiébold, unpublished results ; fig. 1).

Repeated attempts to masculinize the ovary by androgen treatment have failed (Jost ef al., 1963). Therefore, it must be definitively ruled out that the factor responsible 
for modified ovarian differentiation in the freemartin might be an androgen steroid. Perhaps ovarian inhibition in the freemartin and suppression of the Müllerian ducts in the normal male depend on one and the same substance of testicular origin.

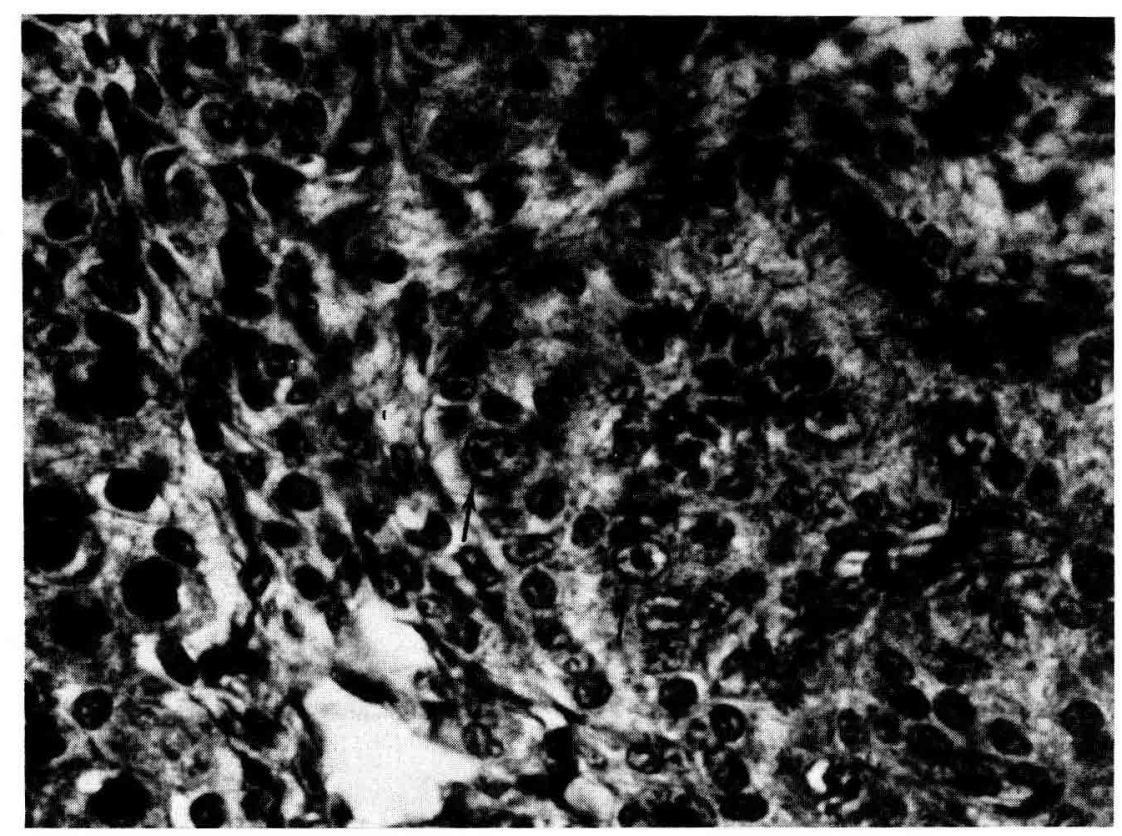

FIG. 1. - Example of a heteroplastic combination of a mouse ovary and a chick testis. The two gonads were from 20- and 8-day-old embryos respectively and were cultured for 7 days on a strip of cellulose acetate filter placed on Wolff and Haffen's medium. Spermatogonia may be seen in the chick testis. $\times 720$.

Estrogen treatment proved more effective on testis feminization at least in marsupials. Beginning œstradiol injections immediately after the young opossums were born, and continuing them until about 30 days postpartum, resulted in strongly feminized testes containing numerous germ cells, some of which had grown to primordial follicles. Because few animals survived after this 30-day treatment, the fate of the $X Y$ oocytes could not be studied further (Burns, 1956).

Zenzes ef $a l$. (1978a and $b$ ) described testicular reorganization of dissociated ovarian cells in presence of $\mathrm{H}-\mathrm{Y}$ antigen.

To summarize, if we exclude the case of the ostrogen treated opossum, sex differentiation of the mammalian gonads can be altered very little. A testicular environment does not prohibit XX germ cells from entering into meiosis, but, on the other hand, it does not provide conditions suitable for oogenesis to proceed beyond the meiotic prophase. In return, ovarian location of an XY germ cell is compatible with full oogenesis. Undoubtedly, the concept of a meiosis-inducing substance is very attractive. Despite the negative results we report here, isolating and characterizing this substance should be the aim of further studies. 


\section{B. - Birds}

As in mammals, parabiosis occurs naturally in double-yolked eggs as a result of vascular anastomoses, but without much modification of the gonads in hetereosexual pairs (Lutz and Lutz-Ostertag, 1959 ; Ruch, 1962).

Grafting an ovary on a male host will result in feminization of the left testis ; in the reverse combination, the gonads of a female host are not modified by a grafted testis (Wolff, 1946-1947).

A broad range of steroids, including both œstrogens and androgens have proved effective in feminizing the male embryo (Wolff and Ginglinger, 1935 ; Wolff, Strudel and Wolff, 1948 ; Haffen, 1969b). The feminized left testis barely differs from a normal ovary, and germ cells in this genetically male, but phenotypically female, gonad may proceed up to the primordial follicle stage. But despite continuing injections after hatching, the chick will revert to its primitive sex (Wolff, 1936-1937).

Fstrogen production by the feminized testis demonstrates functional conversion too (Akram and Weniger, 1969 ; Weniger and Zeis, 1973a and b). It is remarkable that both œstrogens and androgens are capable of inducing this phenomenon. This means that receptors for both groups of steroids are present in the testis or that hormone specificity is not yet clearly established.

The fate of germ cells in a foreign environment has been analysed in a most elegant manner by a combination of culture and graft methods (Haffen, 1969a and 1975).

Female germ cells were allowed to colonize male genital ridges in vitro, which were then grown as grafts. In this way, female germ cells were embedded in a purely male environment, where they developed as spermatogonia. This indicates that female germ cells do not themselves have the capacity to enter into meiosis; the trigger has to be provided by the ovarian somatic tissue. This agrees with the results of the feminization experiments just described. However, as mentioned above, female germ cells initiate meiosis in the testes of chimaeric mice, even if they degenerate soon afterwards (Tarkowski, 1969). If may be argued that these festes did not form only from somatic $X Y$ cells, but also from $X X$ cells which might have contributed the indispensable trigger.

In ovarian somatic tissue, male germ cells are capable of entering into meiosis, but as in the feminized testis, they soon disappear. It may be that completion of meiosis and oocyte growth need the contribution of the $W$ chromosome.

The right rudimentary gonad of the female chick is made up only of medullary cords. This peculiar feature makes it liable to complete sex reversal. Indeed, after left ovariectomy, it develops into a fertile testis (Benoît, 1932-1933 and 1950). Thus, a WZ chromosome constitution is compatible with full spermatogenesis. One case of fertilization of a hen by such a sex-reversed capon has been reported (Champy, 1939).

Raising the incubation temperature above normal has long been known to stabilize the Müllerian ducts in the male embryo (Stoll, 1949). On the other hand, grafting a testis on a female host incubated at the normal temperature of $38^{\circ} \mathrm{C}$ will both suppress the Müllerian ducts and inhibit ovarian development (Thiébold and Reichhart, 1973). At a temperature above normal $\left(40.5^{\circ} \mathrm{C}\right.$ ) neither effect occurs (Thiébold and 
Weniger, unpublished results). We suggest that the anti-Müllerian hormone alone is the cause of both effects, and that its secretion, if not totally abolished, is at least markedly reduced at elevated temperature. Perhaps its supposed protein nature (Weniger et al., 1975) is linked with its temperature sensitivity. Ultrastructural and biochemical studies should shed some light upon this problem.

\section{Conclusion.}

From the work presented, five main conclusions may be drawn :

1) in placental mammals, the freemartin gonad remains the best example of gonadal sex modification ;

2) ovarian differentiation of the festis has been obtained in marsupials, but the short survival of the œstrogen-treated animals did not permit an answer to the question of whether sex reversal would have been definitive or only transient ;

3) germ cells cannot differentiale against their somatic environment. But there are certain limitations which mean that the type of gametogenesis is not automatically in harmony with the modified somatic environment. This is best illustrated by female germ cells undergoing full spermatogenesis in birds, whereas male germ cells, after starting oogenesis, degenerate ;

4) if a meiosis-inducing substance exists, it seems to be species-specific ;

5) in regard to the avian Müllerian hormone, a link is seen between its supposed protein nature and its inactivation by a moderate temperature augmentation.

4th Workshop on « Development and maturation of the reproductive organs and functions 》 Luynes, France, octobre 1978.

Résumé. Le présent travail résume les recherches sur les modifications expérimentales de la différenciation sexuelle des gonades cnez les Mammifères et les Oiseaux. Une attention toute particulière a été accordée au sort des cellules germinales dans un environnement étranger.

Notre propre contribution se rattache au concept d'une substance inductrice de la méiose. Des combinaisons hétérosexuées homoplastiques, hétéroplastiques et xénoplastiques de gonades ont été réalisées. Dans aucun cas, on n'a observé de cellules germinales mâles en prophase méiotique. Les recherches devront être poursuivies avant de pouvoir conclure à l'existence d'une substance inductrice de la méiose.

D'autre part, nous avons montré que l'augmentation de la température d'incubation à $40,5^{\circ} \mathrm{C}$ entraîne l'abolition des effets inhibiteurs que le testicule exerce à $38^{\circ} \mathrm{C}$ sur les canaux de Müller et l'ovaire, chez l'embryon de Poulet. Les deux effets semblent attribuables à l'hormone anti-müllérienne, dont la sensibilité à la température cadre avec l'hypothèse de sa nature protéique.

\section{References}

AKRAM H., WENIGER J.-P., 1969. Sécrétion d'œstrone ef d'œestradiol par les gonades embryonnaires d'oiseaux. Gen. comp. Endocrin., 12, 568-573.

BENOIT J., 1932-1933. Etude physiologique, histologique et histophysiologique de l'inversion sexuelle de la poule déterminée par l'ablation de l'ovaire gauche. Arch. Zool. exp. gén., 73, 1-112. 
BENOIT J., 1950. Reproduction, caractères sexuels et hormones, déterminisme du cycle sexuel saisonnier. In GRASSÉ P.-P., Traité de Zoologie, 15, 384-478.

BURNS R. K., 1956. Transformation du testicule embryonnaire de l'opossum en ovotestis ou en " ovaire " sous l'action de l'hormone femelle, le dipropionate d'œstradiol. Arch. Anat. micr. Morph. exp., 45, 173-202.

BYSKOV A. G., SAXÉN L., 1976. Induction of meiosis in fetal mouse testis in vitro. Develop. Biol., 52, 193-200.

CATTANACH B. M., POLLARD C. E., HAWKES S. G., 1971. Sex-reversed mice : $X X$ and $X O$ males. Cytogenetics, 10, 318-337.

CHAMPY C., 1939. Elevage de poulets de souche exclusivement femelle. C. R. Acad. Sci. Paris, 209, 904-906.

DUNN H. O., KENNEY R. M., LEIN D. H., 1968. XX/XY chimerism in a bovine true hermaphrodite : an insight into the understanding of freemartinism. Cytogenefics, 7, 390-402.

EVANS E. P., FORD C. E., LYON M. F., 1977. Direct evidence of the capacity of the XY germ cell in the mouse to become an ovocyte. Nature (Lond.), 267, 430-431.

FORD C. E., EVANS E. P., BURTENSHAW M. D., CLEGG H. M., TUFFREY M., BARNES R. D., 1975. A functional « sex-reversed » oocyte in the mouse. Proc. roy. Soc. Lond. B, 190, 187-197.

HAFFEN K., 1969a. Incompatibilité entre détermination chromosomique ef stimulation hormonale dans la différenciation sexuelle. Ann. Embr. Morph., Suppl. 1, 223-235.

HAFFEN K., 1969b. Quelques aspects de l'intersexualité expérimentale chez le poulet (Gallus gallus) et la caille (Coturnix coturnix japonica). Bull. biol., 103, 401-417.

HAFFEN K., 1975. Sex differentiation of avian gonads in vifro. Amer Zool., 15, 257-272.

HAMERTON J. L., DICKSON J. M., POLLARD C. E., GRIEVES S. A., SHORT R. V., 1969. Genetic intersexuality in goats. J. Reprod. Fert., Suppl. 7, 25-51.

JOST A., CHODKIEWICZ M., MAULÉON P., 1963. Intersexualité du fœitus de veau produite par des androgènes. Comparaison entre l'hormone fotale responsable du free-martinisme et I'hormone testiculaire adulte. C. R. Acad. Sci. Paris, 256, 274-276.

JOST A., VIGIER B., PRÉPIN J., PERCHELLET J.-P., 1973. Studies on sex differentiation in mammals. Rec. Progr. Horm. Res., 29, 1-41.

KELLER K., TANDLER J., 1916. Über das Verhalten der Eihäute bei der Zwillingsträchtigkeił des Rindes. Wiener tierärzt. Monasschr., 3, 513-526.

LILLIE F. R., 1916. The theory of the free-martin, Science, 43, 611-613.

LUTZ H., LUTZ-OSTERTAG Y., 1959. Free-martinisme spontané chez les oiseaux. Develop. Biol., $1,364-376$.

MACINTYRE M. N., 1956. Effect of the testis on ovarian differentiation in heterosexual embryonic rat gonad transplants. Anat. Rec., 124, 27-45.

MACINTYRE M. N., BAKER L. Jr., WYKOFF T. W., 1959. Effect of the ovary on testicular differentiation in heterosexual embryonic rat gonad transplants. Arch. Anat. micr. Morph. exp., 48 bis, 141-153.

MYSTKOWSKA E. T., TARKOWSKI A. K., 1968. Observations on CBA-P/CBA-T6T6 mouse chimeras. J. Embryol. exp. Morph., 20, 33-52.

MYSTKOWSKA E. T., TARKOWSKI A. K., 1970. Behaviour of germ cells and sexual differentiation in late embryonic and early postnatal mouse chimeras. J. Embryol. exp. Morph., 23, 395-405.

O W.-S., BAKER T. G., 1976. Initiation and control of meiosis in hamster gonads in vitro. J. Reprod. Fert., 48, 399-401.

OZDZENSKI W., ROGULSKA T., BALAKIER H., BRZOZOWSKA M., REMBISZEWSKA A., STEPINSKA U., 1976. Influence of embryonic and adult testis on the differentiation of embryonic ovary in the mouse. Arch. Anat. micr. Morph. exp., 65, 285-294.

RUCH J. V., 1962. Contribution à l'étude des modifications du système génital des embryons issus d'cuufs doubles de poule (Gallus domesticus). Arch. Anat. Hist. Embr., 45, 61-129.

SALZGEBER B., 1963. Modification expérimentale du développement de l'ovaire de souris sous l'influence du testicule embryonnaire de poulet. J. Embryol. exp. Morph., 11, 91-105.

SHORT R. V., SMITH J., MANN T., EVANS E. P., HALLETT J., FRYER A., HAMERTON J. L., 1969. Cytogenetic and endocrine studies of a freemartin heifer and its bull co-twin. Cytogenetics, 8, 369-388. 
STOLL R., 1948. Action de quelques agents physiques et chimiques sur les canaux de Müller de l'embryon de poulet. Arch. Anat. micr. Morph. exp., 37, 333-346.

TARKOWSKI A. K., 1969. Consequences of sex chromosome chimerism for sexual differentiation in mammals. Ann. Embr. Morph., Suppl. 1, 211-222.

TEPLITZ R. L., MOON Y. S., BASRUR P. K., 1967. Further studies of chimerism in heterosexual cattle twins. Chromosoma, 22, 202-209.

THIÉBOLD J. J., REICHHART J.-M., 1973. Inhibition du développement ovarien par la greffe de gonades embryonnaires chez le poulet. C. R. Soc. Biol., 167, 1958-1960.

TURNER C. D., 1969. Experimental reversal of germ cells. Embryologia, 10, 206-230.

TURNER C. D., ASAKAWA H., 1964. Experimental reversal of germ cells in ovaries of fetal mice. Science, 143, 1344-1345.

VIGIER B., LOCATELLI A., PRÉPIN J., DU MESNIL DU BUISSON F., JOST A., 1976. Les premières manifestations du « freemartinisme » chez le foetus de veau ne dépendent pas du chimérisme chromosomique XX/XY. C. R. Acad. Sci. Paris, Sér. D, 282, 1355-1358.

WEISS E., HOFFMANN R., 1969. Eliminierung der $X X$-Zellen im Hoden heterosexueller Rinderzwillinge mit $X X / X Y$-Chimerismus. Cytogenetics, 8, 68-73.

WENIGER J.-P., MACK G., HOLDER F., 1975. L'hormone responsable de la régression des canaux de Müller chez l'embryon de poulet mâle n'est pas un androgène. C. R. Acad. Sci. Paris, Sér. $D, 280,1889-1891$.

WENIGER J.-P., ZEIS A., 1973a. Sécrétion d'une hormone féminisante induite dans le testicule embryonnaire de poulet par la dihydrotestostérone. Arch. Anat. micr. Morph. exp., 62, 173-176.

WENIGER J.-P., ZEIS A., 1973b. Induction de la production d'œstrogènes dans le testicule embryonnaire de poulet par la dihydrotestostérone. Biochimie, 55, 1163-1164.

WOLFF Et., 1936-1937. L'évolution, après l'éclosion, des poulets mâles transformés en intersexués par l'hormone femelle injectée aux jeunes embryons. Arch. Anat. Hist. Embr., 23, 1-38.

WOLFF Et. 1946-1947. Recherches sur l'intersexualité expérimentale produiłe par la méthode des greffes de gonades à l'embryon de poulet. Arch. Anat. micr. Morph. exp., 36, 69-90.

WOLFF Et., GINGLINGER A., 1935. Sur la transformation des poulets mâles en intersexués par injection d'hormone femelle (folliculine) aux embryons. Arch. Anat. Hist. Embr., 20, 219-278.

WOLFF Et., STRUDEL G., WOLFF Em., 1948. L'action des hormones androgènes sur la différenciation sexuelle des embryons de poulet. Arch. Anat. Hist. Embr., 31, 237.308.

ZENZES M. T., WOLF U., GUNTHER E., ENGEL W., 1978a. Studies on the function of H-Y antigen : dissociation and reorganization experiments on rat gonadal tissue. Cytogenet. Cell Genet., 20, 365-372.

ZENZES M. T., WOLF U., ENGEL W., 1978b. Organization in vitro of ovarian cells into testicular structures. Human Genetics, 44, 333-338. 